\title{
Front Matter: Volume 6938
}

, "Front Matter: Volume 6938," Proc. SPIE 6938, Atomic and Molecular Pulsed Lasers VII, 693801 (12 May 2008); doi: 10.1117/12.790997

SDIE Event: Atomic and Molecular Pulsed Lasers VII, 2007, Tomsk, Russian Federation 


\title{
PROCEEDINGS OF SPIE
}

\section{Atomic and Molecular Pulsed Lasers VII}

\author{
Victor F. Tarasenko \\ Editor
}

10-14 September 2007

Tomsk, Russia

Organized by

Institute of Atmospheric Optics (Russia) - High Current Electronics Institute (Russia) • Institute of Monitoring of Climate and Ecological Systems (Russia) • Tomsk State University (Russia)

Tomsk Polytechnic University (Russia) • Physical Institute (Russia) • General Physics Institute

(Russia) • Russian State University for Innovation Technologies and Business (Russia)

Sponsored by

Russian Academy of Sciences (Russia) - Siberian Branch of Russian Academy of Sciences

(Russia) - The Russian Foundation for Basic Research (Russia) • SPIE Russian Chapter • Surgut

State University (Russia) • Laser Association (Russia) • TOPAZ Research and Inculcation

Enterprise (Russia) • Tomsk City Administration (Russia) • Tomsk Municipal Duma (Russia)

Media Sponsors

Advances in Optical Technologies Journal (USA) • Obzor.Westsib.RU (Russia)

Published by

SPIE

Volume 6938 
The papers included in this volume were part of the technical conference cited on the cover and title page. Papers were selected and subject to review by the editors and conference program committee. Some conference presentations may not be available for publication. The papers published in these proceedings reflect the work and thoughts of the authors and are published herein as submitted. The publisher is not responsible for the validity of the information or for any outcomes resulting from reliance thereon.

Please use the following format to cite material from this book:

Author(s), "Title of Paper," in Atomic and Molecular Pulsed Lasers VII, edited by Victor F. Tarasenko, Proceedings of SPIE Vol. 6938 (SPIE, Bellingham, WA, 2007) Article CID Number.

ISSN 0277-786X

ISBN 9780819471253

Published by

SPIE

P.O. Box 10, Bellingham, Washington 98227-0010 USA

Telephone +1 3606763290 (Pacific Time) · Fax +1 3606471445

SPIE.org

Copyright (C 2008, Society of Photo-Optical Instrumentation Engineers

Copying of material in this book for internal or personal use, or for the internal or personal use of specific clients, beyond the fair use provisions granted by the U.S. Copyright Law is authorized by SPIE subject to payment of copying fees. The Transactional Reporting Service base fee for this volume is $\$ 18.00$ per article (or portion thereof), which should be paid directly to the Copyright Clearance Center (CCC), 222 Rosewood Drive, Danvers, MA 01923. Payment may also be made electronically through CCC Online at copyright.com. Other copying for republication, resale, advertising or promotion, or any form of systematic or multiple reproduction of any material in this book is prohibited except with permission in writing from the publisher. The CCC fee code is $0277-786 \mathrm{X} / 08 / \$ 18.00$.

Printed in the United States of America.

Publication of record for individual papers is online in the SPIE Digital Library.

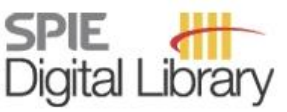

SPIEDigitallibrary.org

Paper Numbering: Proceedings of SPIE follow an e-First publication model, with papers published first online and then in print and on CD-ROM. Papers are published as they are submitted and meet publication criteria. A unique, consistent, permanent citation identifier (CID) number is assigned to each article at the time of the first publication. Utilization of CIDs allows articles to be fully citable as soon they are published online, and connects the same identifier to all online, print, and electronic versions of the publication. SPIE uses a six-digit CID article numbering system in which:

- The first four digits correspond to the SPIE volume number.

- The last two digits indicate publication order within the volume using a Base 36 numbering system employing both numerals and letters. These two-number sets start with 00, 01, 02, 03, 04, 05, $06,07,08,09,0 A, 0 B \ldots 0 Z$, followed by $10-12,20-2 Z$, etc.

The CID number appears on each page of the manuscript. The complete citation is used on the first page, and an abbreviated version on subsequent pages. Numbers in the index correspond to the last two digits of the six-digit CID number. 


\title{
Contents
}

\author{
vii Conference Committee \\ ix Introduction
}

\section{GAS AND PLASMA LASERS}

693803 Nitrogen, atomic fluorine and $\mathrm{CO}_{2}$ lasers excited by a pulsed inductive discharge [6938-02] A. M. Razhev, A. A. Zhupikov, D. S. Churkin, Institute of Laser Physics (Russia)

693804 Development of compact UV lasers with pulse repetition rate up to $5 \mathrm{kHz}$ [6938-03] A. V. Andramanov, S. A. Kabaev, B. V. Lazhintsev, V. A. Nor-Arevyan, A. V. Pisetskaya, V. D. Selemir, Russian Federal Nuclear Ctr. (Russia)

693805 Recent progress in discharge-based soft x-ray lasers at IPP ASci CR [6938-04] K. Kolacek, J. Schmidt, V. Prukner, O. Frolov, J. Straus, Institute of Plasma Physics (Czech Republic)

693806 Use of excimer media for formation of short high-power laser radiation pulses [6938-05] V. F. Losev, N. G. Ivanov, Yu. N. Panchenko, Institute of High Current Electronics (Russia)

693807 Optimization of gas dynamic and power parameters for continuous nuclear pumped laser [6938-06]

A. N. Korzenev, A. N. Sizov, Nuclear and Radiation Physics Institute (Russia)

693808 TEA $\mathrm{CO}_{2}$ laser with pulse repetition rate above $3 \mathrm{kHz}$ [6938-07]

A. V. Andramanov, S. A. Kabaev, B. V. Lazhintsev, V. A. Nor-Arevyan, A. V. Pisetskaya, V. D. Selemir, Russian Federal Nuclear Ctr. (Russia)

693809 Efficient $\mathrm{KrCl}(223 \mathrm{~nm})$ excimer laser based on TPI thyratron as a high-voltage switch [6938-08]

A. M. Razhev, A. A. Zhupikov, Institute of Laser Physics (Russia)

6938 OB Experimental study of capacitive periodic-pulsed discharge applied to active medium ionization in gas lasers with combined discharges [6938-10]

A. Yu. Kedrov, V. A. Kuznetsov, A. N. Shemyakin, N. G. Solov'yov, M. Yu. Yakimov, V.P. Zimakov, Institute for Problems in Mechanics (Russia)

6938 OC Use of SBS mirror for formation of high quality short pulses in excimer laser [6938-11] V. F. Losev, Yu. N. Panchenko, Institute of High Current Electronics (Russia)

6938 OD Forming of optical radiation of multi-channel nuclear-pumped lasers [6938-12] A. A. Pikulev, S. V. Patyanin, A. A. Sinyanskii, P. V. Sosnin, S. L. Turutin, V. M. Tsvetkov, Russian Federal Nuclear Ctr. (Russia) 
6938 OG The nature of the photoprocesses in the new 7-hydroxycoumarines [6938-15]

T. N. Kopylova, L. G. Samsonova, R. M. Gadirov, Tomsk State Univ. (Russia); V. P. Khilya,

V. V. Ishchenko, O. V. Shablykina, Shevchenko State Univ. (Ukraine)

$6938 \mathrm{OH} \quad$ Active media on the basis of hybrid nanocomposites for tunable lasers [6938-16]

T. N. Kopylova, G. V. Mayer, E. N. Tel'minov, V. A. Svetlichnyi, Tomsk State Univ. (Russia);

T. A. Solodova, Institute of Petroleum Chemistry (Russia); E. A. Vaitulevich,

K. M. Degtyarenko, N. S. Eremina, L. G. Samsonova, Tomsk State Univ. (Russia)

\section{PHYSICAL PROCESSES IN GAS LASERS}

6938 0J Possible use of ion-ion recombination in nuclear pumped laser [6938-18]

I. I. Smirnova, M. U. Khasenov, Nauka L, LLC (Kazakhstan)

6938 OK Kinetics of the energy transformation in the discharge pumped $\mathrm{XeCl}$ laser [6938-19]

Y. I. Bychkov, A. G. Yastremsky, S. A. Yampolskaya, Institute of High Current Electronics (Russia)

$6938 \mathrm{OL}$ Spatial and temporal evolution of current density in spatially inhomogeneous discharge in gas mixtures with $\mathrm{SF}_{6}$ [6938-20]

Y. I. Bychkov, A. G. Yastremsky, S. A. Yampolskaya, Institute of High Current Electronics (Russia)

6938 OM Discharge current and current of supershort avalanche E-beam at volume nanosecond discharge in non-uniform electric field [6938-21]

V. F. Tarasenko, D. V. Rybka, E. H. Baksht, I. D. Kostyrya, M. I. Lomaev, Institute of High

Current Electronics (Russia)

6938 ON Scaling of strontium-vapor laser active volume [6938-22]

A. N. Soldatov, Tomsk State Univ. (Russia) and West Siberian Branch of Russian State Univ. for Innovation Technologies and Business (Russia); Yu. P. Polunin, Tomsk State Univ. (Russia)

693800 Laser dyes excited by high PRR Nd:YAG laser second-harmonic radiation [6938-23] A. N. Soldatov, Tomsk State Univ. (Russia) and West Siberian Branch of Russian State Univ. for Innovation Technologies and Business (Russia); V. I. Donin, D. V. Jakovin, Institute of Automation and Electrometry (Russia); I. V. Reimer, Tomsk State Univ. (Russia) and LITT, Ltd. (Russia)

\section{LASER SYSTEMS AND NEW LASER AND OPTICAL TECHNOLOGIES: APPLICATIONS}

6938 OP Electron accelerator for pumping of XeF (C-A) femtosecond pulse amplifier [6938-24]

N. G. Ivanov, V. F. Losev, Institute of High Current Electronics (Russia)

6938 OR Optical ceramics from neodymium-activated yttrium oxide [6938-26]

S. N. Bagayev, Institute of Laser Physics (Russia); V. V. Osipov, M. G. Ivanov, V. I. Solomonov, V. V. Platonov, A. N. Orlov, A. V. Rasuleva, V. V. Ivanov, A. S. Kaygorodov, V. R. Khrustov, Institute of Electrophysics (Russia); S. M. Vatnik, I. A. Vedin, A. P. Mayorov, E. V. Pestryakov, Institute of Laser Physics (Russia); A. V. Shestakov, A. V. Salkov, JSC ELAKOM (Russia) 
6938 ОT Optical acoustic experimental investigation of propagation femtosecond laser radiation in air and biological tissues [6938-28]

N. N. Bochkarev, A. M. Kabanov, E. S. Protasevich, Institute of Atmospheric Optics (Russia); A. N. Stepanov, Institute of Applied Physics (Russia)

6938 OW Femtosecond XeF(C-A) laser amplifier pumped by radiation of multichannel surface discharges [6938-31]

V. Tcheremiskine, O. Uteza, Lab. LP3, Univ. Aix-Marseille II (France); A. Aristov, P.N. Lebedev Physical Institute (Russia); M. Sentis, Lab. LP3, Univ. Aix-Marseille II (France); L. Mikheev, P.N. Lebedev Physical Institute (Russia)

6938 0X Treatment of basal-cellular skin cancer and heavy concomitant diseases by a photodynamic therapeutic method with a dye laser LITT-PDT [6938-32]

V. A. Evtushenko, Oncological Research Institute (Russia); A. N. Soldatov, Tomsk State Univ. (Russia); M. V. Vusik, Oncological Research Institute (Russia); I. V. Reimer, LITT, Ltd. (Russia)

\section{NONCOHERENT UV AND VUV SOURCES}

6938 OY VUV-VIS imaging of high-pressure pulsed discharge in argon [6938-33]

A. B. Treshchalov, A. A. Lissovski, Univ. of Tartu (Estonia)

$69380 Z$ Sources of spontaneous narrow-band UV and VUV radiation [6938-34]

D. V. Schitz, V. F. Tarasenko, V. S. Skakun, M. I. Lomaev, S. M. Avdeev, Institute of High Current Electronics (Russia)

693810 Innovative power supply concepts for DBD excilamps [6938-35]

H. Piquet, S. Bhosle, R. Díez, A. Toumi, G. Zissis, Univ. de Toulouse (France)

693811 The various dielectric barrier discharges lamps and plasma panel prototype designs developed in VNIIEF [6938-36]

V. M. Tsvetkov, A. A. Pikulev, Russian Federal Nuclear Ctr. (Russia)

693813 Comparative study of UV radiation action of XeBr-excilamp and conventional lowpressure mercury lamp on bacteria [6938-38]

S. M. Avdeev, E. A. Sosnin, Institute of High Current Electronics (Russia);

K. Yu. Velichevskaya, L. V. Lavrent'eva, Tomsk State Univ. (Russia)

693815 A new method of chlorophenols decomposition based on UV-irradiation by XeBr-excilamp and their subsequent biodegradation [6938-40]

E. A. Sosnin, Institute of High Current Electronics (Russia); G. G. Matafonova, V. B. Batoev, Baikal Institute of Nature Management (Russia); N. Christofi, Napier Univ. (United Kingdom)

693817 The investigation of excimer $\operatorname{XeF}^{*}(\sim 354 \mathrm{~nm})$ emission efficiency at excitation $\mathrm{Xe} / \mathrm{SF}_{6}$ mixture by barrier discharge [6938-42]

A. A. Pikulev, V. M. Tsvetkov, Russian Federal Nuclear Ctr. (Russia)

Author Index 
Downloaded From: https://www.spiedigitallibrary.org/conference-proceedings-of-spie on 26 Apr 2023

Terms of Use: https://www.spiedigitallibrary.org/terms-of-use 


\title{
Conference Committee
}

\author{
International Organizing Committee \\ Chairman: Victor F. Tarasenko (Russia) \\ Co-Chairman: Vladimir M. Klimkin (Russia) \\ Co-Chairman: Georgiy V. Mayer (Russia) \\ Co-Chairman: Georgiy G. Petrash (Russia) \\ Scientific Secretary: Gennadiy S. Evtushenko (Russia) \\ Editor: Mikhail V. Erofeev (Tomsk, Russia) \\ Edmund I. Akopov (Russia) \\ Yuriy M. Andreev (Russia) \\ Slavomir S. Anufrik (Belarus) \\ Alexander M. Boychenko (Russia) \\ Peter A. Bokhan (Russia) \\ Oleg B. Danilov (Russia) \\ J. Gary Eden (USA) \\ Konstantin N. Firsov (Russia) \\ Andrey A. Ionin (Russia) \\ Tatiyana N. Kopylova (Russia) \\ Mahadevan Krishnan (USA) \\ Evgeniy L. Latush (Russia) \\ Victor M. Lisitsyn (Russia) \\ Jingru Liu (China) \\ Valeriy F. Losev (Russia) \\ Richard P. Mildren (Australia) \\ Utpal Nundy (India) \\ Vladimir V. Osipov (Russia) \\ Antonio Palucci (Italy) \\ Alexander M. Razhev (Russia) \\ Nikola V. Sabotinov (Bulgaria) \\ Anatoliy A. Sinianskiy (Russia) \\ Anatoliy N. Soldatov (Russia) \\ Aleksey Trestchalov (Estonia) \\ Milan Trtica (Serbia) \\ Andreas Ulrich (Germany) \\ Sergey I. Yakovlenko (Russia)

\section{Organizing Committee}

Chairman: Victor F. Tarasenko (Tomsk, Russia)

Co-Chairman: Gennadiy S. Evtushenko (Tomsk, Russia)

Scientific Secretary: Mikhail V. Erofeev (Tomsk, Russia)

Scientific Secretary: Anton V. Klimkin (Tomsk, Russia)

Secretary: Ekaterina Yu. Kiselyova (Tomsk, Russia) 
Secretary: Elena K. Klimkina (Tomsk, Russia)

Anatoliy I. Fyodorov (Tomsk, Russia)

Pavel P. Geiko (Tomsk, Russia)

Gennadiy N. Gerasimov (St. Petersburg, Russia)

Mishik A. Kazaryan (Moscow, Russia)

Tatiana N. Kopylova (Tomsk, Russia)

Mikhail E. Levitskiy (Tomsk, Russia)

Mikhail M. Makogon (Tomsk, Russia)

Georgiy I. Nazin (Surgut, Russia)

Georgiy G. Petrash (Moscow, Russia)

Igor E. Sokolovskiy (Tomsk, Russia)

Anatoliy N. Soldatov (Tomsk, Russia)

Edward A. Sosnin (Tomsk, Russia)

Valeriy A. Svetlichnyi (Tomsk, Russia)

Vladimir O. Troitskiy (Tomsk, Russia)

Anna V. Vasilyeva (Tomsk, Russia)

Alexandra M. Yancharina (Tomsk, Russia) 


\section{Introduction}

This volume includes the most interesting papers presented at the VIII International Conference Atomic and Molecular Pulsed Lasers (AMPL-2007). The conference was held on September 10-14, 2007 as per tradition in Tomsk - the ancient town in Siberia. The AMPL conference is one of the most visited events in Russia related to the laser physics area of research.

This year about 186 participants from Russia, Germany, France, Italy, Serbia, USA, Czech Republic, Estonia, Belarus, and Kazakhstan took part in the conference, and 223 presentations, including 35 invited papers and 98 oral ones, were delivered. About 50 students from Tomsk institutes of higher education also participated in the conference as well as audience.

The program of the AMPL-2007 conference included the conventional seven sessions:

- Gas and plasma lasers

- Metal vapor lasers

- Dye lasers and photoprocesses in complex organic molecules

- Physical processes in gas lasers

- Laser systems and new laser and optical technologies: applications

- Noncoherent UV and VUV sources

- Laser output conversion: optoelectronic devices

This year's conference was devoted to Professors V. M. Klimkin and S. I. Yakovlenko, members of AMPL conference organizing committees for many years. This year the scientific community lost both of them.

Special attention at the conference was paid to the research and development of many types of pulsed gas lasers, creation of laser systems with high radiating power, physics of gas discharge, UV and VUV radiation sources, interaction of laser radiation with matter, and many applications of gas lasers, including applications in micro- and nano-technologies. The plenary session, held on September 10, included presentations related to these topics, and altogether 14 papers were delivered.

Professor A. Ulrich from Munich Technical University, Garching, Germany gave the first presentation, which reported on the generation of the molecules KrF* for the first time at excitation by a beam of heavy ions. Dr. A. M. Boichenko reported in brief on the most important scientific results obtained by Professor S. I. Yakovlenko, and Professor G. S. Evtushenko presented the most important results obtained by V. M. Klimkin. Professor K. Kolacek from the Institute of Plasma Physics AS CR, Prague, Czech Republic presented a review devoted to soft X-rays based electrodischarge lasers. A presentation by S. Bhosle and H. Piquet, "Innovative Power Supply Concepts for DBD Excilamps" (University of Toulouse, Toulouse, 
France), was devoted to the development of excilamps drivers, possessing the high efficiency of energy transfer to a load. Professor A. N. Soldatov from Tomsk State University, Tomsk, Russia discussed new results related to the development of the strontium IR-laser and its application. "Surface Modification of Bio-Materials by Nanosecond and Picosecond Laser Pulses" was delivered by Dr. M. S. Trtica from the Vinca Institute of Nuclear Sciences, Belgrade, Serbia. Dr. B. Lacour from Paris-Sub University, Orsay, France presented "Microdischarge Production of Singlet Oxygen". Singlet oxygen is used in the creation of chemical lasers with high mean radiating power. Professor V. F. Tarasenko presented an overview of works of the Laboratory of Optical Radiation, Institute of High Current Electronics SB RAS, Tomsk, Russia. Dr. A. B. Treshchalov from the University of Tartu, Tartu, Estonia delivered the paper "VUV-VIS Imaging of High-Pressure Pulsed Discharge in Argon". The presentation by Professor A. A. Ionin from Physical Institute RAS, Moscow, Russia reported on research related to the creation of a high-power femtosecond laser system. Profs. and Drs. P. A. Bokhan, Yu. M. Andreev, and M. M. Makogon also presented at the plenary session. Professor G. G. Matvienko, director of the Institute of Atmospheric Optics, opened the conference and acquainted the participants with the research and development program of the institute.

During the conference the participants visited laboratories at the Institute of Atmospheric Optics and the Institute of High Current Electronics, Siberian Branch of Russian Academy of Sciences.

The next international conference on Atomic and Molecular Pulsed Lasers (AMPL09) will be held in Tomsk on September 14-18, 2009.

Victor F. Tarasenko Georgiy G. Petrash 